\title{
The Role of Effective Communication in Enhancing Leadership Skills Among Students of Bachelor of Management Mathematics in UiTM Perlis
}

\author{
Nur Fatin Amira Anuar', Nur Fatihah Fauzi², Huda Zuhrah Ab Halim³, Nur Izzati Khairudin ${ }^{4}$, \\ Nurizatul Syarfinas Ahmad Bakhtiar ${ }^{5}$, Nor Hayati Shafii ${ }^{6}$ \\ 1,2,3,4,5,6 Faculty of Computer and Mathematical Sciences, \\ Universiti Teknologi MARA Perlis Branch, Arau Campus, 02600 Arau, Perlis, Malaysia
}

Corresponding author: *fatihah@uitm.edu.my

Received Date: 15 August 2021

Accepted Date: 1 September 2021

Published Date: 20 September 2021

\section{HIGHLIGHTS}

- Communication is the most important key factor for a student to lead effectively because it helps them to express their opinion.

- It is important for students need to have effective communication because it helps them develop their leadership skills and can also improvise on their self-confidence.

- There are three independent variables (IV) such as effective listening, performing tasks completely and effectively, and clarity of thought and expression:

- Leadership skills are used for dependent variables (DVs).

\begin{abstract}
Communication is the most important key factor for a student to lead effectively because it helps them to express their opinion. Some students are struggling to socialise with other students due to a lack of communication skills. It is important for students to have effective communication because it helps them develop their leadership skills and can also improvise their self-confidence. The purpose of this study was to identify the level of effective listening, performing tasks completely and effectively, clarity of thought and expression, and leadership skills, to assess the significant difference of demographic variables (gender, age, and semester) on effective listening, performing tasks completely and effectively, clarity of thought and expression and leadership skills, to determine the relationship between effective listening, performing tasks completely and effectively, clarity of thought and expression and leadership skills, and lastly to examine whether effective listening, performing tasks completely and effectively, clarity of thought and expression relate toward leadership skills. The random sample of 155 respondents is from the Faculty of Computer and Mathematical Science (FSKM) at UiTM Perlis. To achieve all the objectives, the researcher has chosen to apply the frequency test, the independent t-Test, the one-way ANOVA, the correlation, and regression performed by the Statistical Package for Social Sciences Version 20.0. (SPSS). Based on the findings, there is a positive relationship between the role of effective communication and leadership skills, but a great deal of determination is still needed to establish leadership criteria among undergraduates, as a few students have not been aware of the importance of leadership skills in their future careers. Moreover, the analysis shows that clarity of thought and expression are the most important roles that contribute to leadership skills. The role of effective communication in enhancing leadership skills among university students must be properly studied so that students can develop their ability to soon become major leaders.
\end{abstract}


Keywords: effective communication, leadership skills, ANOVA, independent t-test, regression, correlation, SPSS

\section{INTRODUCTION}

Communication is the key organisational development tool for social interactions. Good communication skills are needed to convey ideas to others. Communication is also the key factor that enables a leader to lead effectively. The organisation is made up of employees, managers, customers, and investors. Effective communication helps a leader voice his or her thoughts to an organisation. Each group of an organisation may require a different style of leadership communication.

Kelvin (2016) states that verbal communication occurs mainly in a face-to-face situation. Verbal communication helps people exchange thoughts, feelings, and opinions. According to Abdan (2015), there are different ways to communicate, such as speech, writing, or sign. Verbal communication is a process for a person to deliver a voice message of his or her opinion so that the other party understands what he or she wants to share. Good communication is helping people pay attention to the presenter. A great communicator and a first-class communicator are the characteristics needed to become a leader (Luthra \& Dahiya, 2015). Abdan (2015) concluded that communication and leadership are a great combination to make people succeed in their profession.

The role of successful communication is by listening. According to Caspersz \& Stasinska (2015), effective listening is more than a cognitive process in which listeners need to understand verbal and non-verbal communication. For example, a conversation could only take place if the person and the receiver were standing. However, they had to avoid having a conversation when one person is standing while the other is sitting because effective communication requires eyes to eyes level to circumvent misunderstanding. People must avoid crossing their arms because they convey egotism or disagreement. It will help to build relationships and understanding with someone else (Abdan, 2015).

Moreover, the role of effective communication is clarity of thought and expression. There are non-verbal cues such as a smile, a panting, a shrugging of the shoulder, and a glaring that have meaning and are well understood in our culture. However, the meaning behind these indirect behaviours is unknown. Akilandeswari et al. (2015) stated that a person must first identify what and why he or she needs to send a message to the other person. Burg (2020) has stated that the burden of clarity in communication is always on the communicator. The communicator is the person who is committed to a common understanding for effective communication to take place. It is therefore important to make sure that what we mean is what we hear, and that what we hear is what we mean.

According to Ayub et al. (2014), leadership comes from a single word, 'leader,' which means a person or thing that can lead other people to succeed. Successful leaders are always trying to maintain a good balance by changing their leadership methods, which also has an impact on communication (Luthra \& Dahiya, 2015). Henderson (2015) stated that the leadership's communication practices need to embrace and maintain good working relations. Leaders who have a good working knowledge of the organisation, therefore, may have the benefit of knowing what has gone before and may use that experience in discussions with staff members.

According to Akilandeswari et al. (2015), communication is crucial to making human beings and organisations successful. A person needs to have the ability to communicate effectively at home, at school, at work, and Wikaningrum et al. (2018) conducted a study on all staff at several private Islamic universities 
in Semarang city, Indonesia. It shows that effective communication plays a crucial role in enhancing the leadership skills that can be used, particularly at work, in the future.

This study explores the role of effective communication in enhancing leadership skills among UiTM Perlis students. There are three independent variables (IV) such as effective listening, performing tasks completely and effectively, and clarity of thought and expression. The leadership skills will be used as dependent variables (DVs).

\section{METHODOLOGY}

This is a quantitative study. The objective of this study can be achieved by selecting each unit in the sample frame of students at Universiti Teknologi MARA Cawangan Perlis, Kampus Arau. Quantitative research provides a method for making information accessible to audiences and standardised approaches allow the study to be reproduced over time (Goertzen, 2017). The advantages of using this method, such as taking less time to collect data and making it cheaper, because all data were collected at the same time.

\section{Population and Sample}

The population of this study consisted of degree students from Universiti Teknologi MARA Cawangan Perlis, Kampus Arau from the Faculty of Computer Science and Mathematics. Based on Majid (2018), the researcher needs to extract a sample from the targeted students for the study. The study sample is 155 Bachelor of Science (Hons.) Management Mathematics (CS248). The population sample will decide based on the Krejcie and Morgan tables (Krejcie \& Morgan, 1970). The students who take the course are 258 from semester one to semester eight.

\section{Theoretical Framework}

This theoretical framework was adapted by Luthra \& Dahiya (2015). The model measures the role of effective communication in enhancing leadership skills among UiTM Perlis students based on effective listening, performing tasks completely and effectively, and clarity of thought and expression.
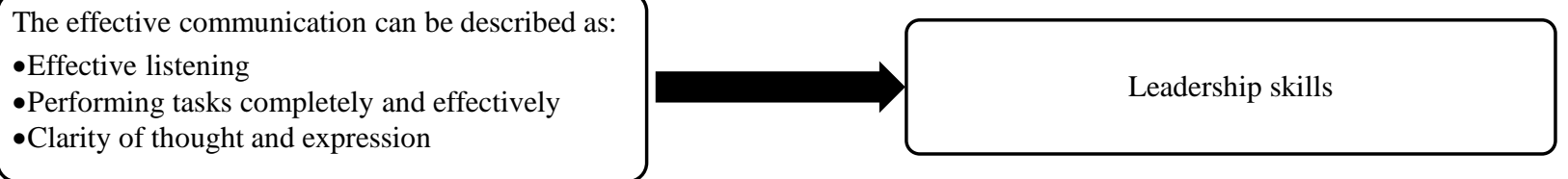

Figure 1: Theoretical Framework of the Study

\section{Research Instrument}

The study uses questionnaires for the research instrument, including several questions, to gather feedback and information from the respondents. The respondents were asked to answer all items in the questionnaire based on five-point Likert-type scales; $1=$ strongly disagree, $2=$ disagree, $3=$ neutral, $4=$ agree and $5=$ strongly agree.

Five sections cover the questionnaires:

1) Section A: Respondent's Information

2) Section B: Leadership Skills

3) Section C: Effective Listening

4) Section D: Performing Tasks Completely and Effectively 


\section{5) Section E: Clarity of Thought and Expression}

\section{Method of Data Collection}

The data for this study is collected directly from the respondents through online questionnaires via various mediums such as email, WhatsApp, and telegram. To encourage participation from the respondents, researcher briefly explained the purpose of the study and made it clear to the participants that participation in the research was voluntary and anonymous (the respondents' identities would be kept confidential). This way was found very useful to clarify any doubt among participants in the survey and to motivate the participant to be more open and honest in his/her answers (Sekaran \& Bougie, 2010). In addition, the researcher explained to the participants how to complete the questionnaire and allowed them to take about a week to complete the questionnaire.

The questionnaires will be prepared in two different languages, English and Bahasa Malaysia. This is because some respondents may have difficulty to understand the questionnaires and making it easier for respondents to respond to the questions asked. The quantitative research method used in this study depends on the primary questionnaire data of 155 respondents. Out of 155 questionnaires that had been distributed, all the set questionnaires successfully returned by students. According to Ary et al. (2002) the typical return of a questionnaire can reach between 70 to 90 percent of the return once administered. This shows that the process of data analysis to obtain research findings can be carried out.

\section{Method of Data Analysis}

The analysis of the study is carried out by the Statistical Package for Social Science Version 20.0 (SPSS), where it includes the modification of the raw data. The analysis can be done by adjusting the raw data collected to get the information. The SPSS is used to understand and interpret research findings. The data analysis used is a frequency test, independent t-test, one-way ANOVA, and regression. The SPSS software programmes can be used by selecting the appropriate menu to test each objective using the applicable statistical test.

Table 1: Statistical Techniques in Data Analysis

\begin{tabular}{|l|l|}
\hline $\begin{array}{l}\text { Statistical } \\
\text { Techniques }\end{array}$ & \multicolumn{1}{|c|}{ Objectives } \\
\hline Frequency Test & $\begin{array}{l}\text { To identify the level of effective listening, performing tasks completely and effectively, and clarity of } \\
\text { thought and expression and leadership skills. }\end{array}$ \\
\hline Independent t-Test & $\begin{array}{l}\text { To compare the values of the means from two samples and test whether it is likely that the samples are } \\
\text { from populations having different mean values. }\end{array}$ \\
\hline One-way ANOVA & To compare the means of more than two groups based on a single treatment factor. \\
\hline Regression & $\begin{array}{l}\text { To examine whether effective listening, performing tasks completely and effectively, and clarity of } \\
\text { thought and expression toward leadership skills. }\end{array}$ \\
\hline
\end{tabular}

\section{Pilot Study}

A pilot study was conducted in this research to ensure the reliability of the questionnaire. Moreover, the questions are easily understood by the students. The pilot study was conducted with respondents with similar characteristics to the target population. Fifteen respondents from the target population took part in the pilot study. The pilot study questionnaire consisted of 20 items that the respondents needed to respond to, including demographic information. The reliability test based on the Cronbach's Alpha results shown in Table 2 is as follows:

Table 2: Reliability Test for Pilot Study 


\begin{tabular}{|c|c|c|}
\hline Variables & Number of Items & Cronbach Alpha \\
\hline Leadership Skills & 4 & 0.665 \\
\hline Effective Listening & 4 & 0.769 \\
\hline $\begin{array}{l}\text { Performing Tasks } \text { Completely and } \\
\text { Effectively }\end{array}$ & 4 & 0.730 \\
\hline Clarity of Thought and Expression & 4 & 0.665 \\
\hline
\end{tabular}

Based on the above table, it shows that the reliability measurement for all variables was greater than 0.6. It indicates that there is a good internal consistency of the measurement items in each scale. Thus, the instrument used in these studies is reliable for the actual study.

\section{FINDINGS AND DISCUSSIONS}

The findings of this study are based on the response given by the respondent to the questionnaire that was distributed and were evaluated to meet all of the specified objectives of this study.

\section{Level of Students Understandings about Leadership Skills}

Descriptive analysis involving mean and standard deviation was conducted to determine the role of effective communication in enhancing student leadership skills. The results of the descriptive analysis as shown in Tables $3-6$.

Table 3: Level of Students Understanding about Leadership Skills

\begin{tabular}{clccc}
\hline No. & Items & Mean & Std. Deviation & Interpretation Score \\
\hline 1 & A leader must be able to motivate others. & 4.74 & 0.457 & High \\
\hline 2 & A leader can identify the nature of a problem. & 4.78 & 0.415 & High \\
\hline 3 & A leader is required to respond to people's requests and concerns. & 4.67 & 0.471 & High \\
\hline 4 & A leader should be flexible about making changes in his leadership. & 4.68 & 0.466 & High \\
\hline & Overall & 4.72 & 0.452 & High \\
\hline
\end{tabular}

Based on the Table 3, the item of leadership skills that have the high mean is "A leader can identify the nature of a problem" (mean $=4.78$ and std. deviation $=0.415)$. The overall mean of leadership skills is (mean $=4.72$ and std. deviation $=0.452$ ). The students' level of understanding of leadership skills is therefore at a high level.

Table 4: Level of Students Understanding about Effective Listening

\begin{tabular}{clccc}
\hline No. & \multicolumn{1}{c}{ Items } & Mean & Std. Deviation & \multicolumn{2}{c}{ Interpretation Score } \\
\hline 1 & A leader needs to engage in matters important about their employee. & 4.73 & 0.446 & High \\
\hline 2 & A leader has to be empathic. & 4.64 & 0.482 & High \\
\hline 3 & A leader listens and do not interrupt the flow of the dialogue. & 4.70 & 0.461 & High \\
\hline 4 & A leader must be an active listener. & 4.72 & 0.449 & High \\
\hline Overall & 4.69 & 0.460 & High \\
\hline
\end{tabular}

Based on the Table 4, the item of effective listening that have the high mean is "A leader needs to engage in matters important about their employee" (mean $=4.73$ and std. deviation $=0.446)$. The overall mean of effective listening is (mean $=4.69$ and std. deviation $=0.460$ ). The level of students understanding effective listening is therefore at a high level.

Table 5: Level of Students Understanding about Performing Tasks Completely and Effectively

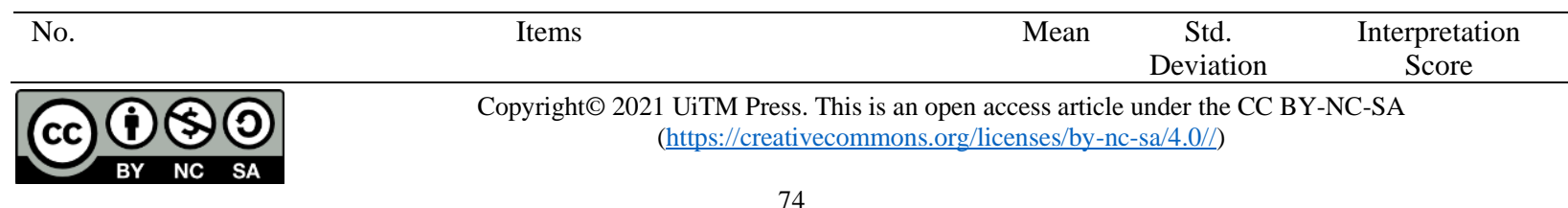




\begin{tabular}{llrrr}
\hline 1 & A leader will finish his/her work in order of priority. & 4.66 & 0.474 & High \\
\hline 2 & A leader must be confident enough. & 4.70 & 0.461 & High \\
\hline 3 & $\begin{array}{l}\text { A leader should be able to complete what needs to be done during normal } \\
\text { office hour. }\end{array}$ & 4.61 & 0.489 & High \\
\hline 4 & A leader should spend enough time on planning his/her activity. & 4.70 & 0.458 & High \\
\hline & Overall & 4.67 & 0.471 & High \\
\hline
\end{tabular}

Based on the Table 5, the item of performing tasks completely and effectively that have the high mean is "A leader should spend enough time on planning his/her activity" (mean $=4.70$ and std. deviation $=0.458)$. The overall mean for performing tasks completely and effectively is (mean $=4.67$ and std. deviation $=$ 0.471). The level of students' understanding of performing tasks is therefore completely and effectively at a high level.

Table 6: Level of Students Understanding about Clarity of Thought and Expression

\begin{tabular}{llccc}
\hline No. & \multicolumn{1}{c}{ Items } & Mean & $\begin{array}{c}\text { Std. } \\
\text { Deviation }\end{array}$ & $\begin{array}{c}\text { Interpretation } \\
\text { Score }\end{array}$ \\
\hline 1 & A leader usually knows how to respond to a new idea. & 4.71 & 0.483 & High \\
\hline 2 & $\begin{array}{l}\text { When communicating to their community, a leader should pay attention to } \\
\text { their body language. }\end{array}$ & 4.72 & 0.449 & High \\
\hline 3 & $\begin{array}{l}\text { When the community talk to a leader, the leader should respect their } \\
\text { perspective. }\end{array}$ & 4.64 & 0.482 & High \\
\hline 4 & $\begin{array}{l}\text { Before expressing his/her opinion, a leader should find a way to say in the } \\
\text { most proper manner. }\end{array}$ & 4.70 & 0.458 & High \\
\hline & Overall & 4.69 & 0.468 & High \\
\hline
\end{tabular}

Based on Table 6, the item of clarity of thought and expression that has a high mean is "When communicating to their community, a leader should pay attention to their body language" (mean $=4.72$ and std. deviation $=0.449$ ). The overall mean for clarity of thought and expression is (mean $=4.69$ and std. deviation $=0.468$ ). Thus, the level of students' understanding of clarity of thought and expression is at a high level.

\section{The Role of Effective Communication in Enhancing Leadership Skills Based on Gender Using Independent t-Test}

Differences in the role of effective gender-based communication are supported by the Independent T-Test analysis. The results of the analysis are shown in the following table:

Table 7: Results of t-Test Analysis

\begin{tabular}{|c|c|c|c|c|c|c|}
\hline Variables & Gender & $\mathrm{N}$ & Mean & Std. Deviation & $\mathrm{t}$ & $\mathrm{p}$ \\
\hline \multirow[t]{2}{*}{ Leadership Skills } & Male & 45 & 18.5111 & 1.35885 & \multirow[t]{2}{*}{-2.362} & \multirow[t]{2}{*}{.019} \\
\hline & Female & 110 & 19.0182 & 1.14925 & & \\
\hline \multirow[t]{2}{*}{ Effective Listening } & Male & 45 & 18.9778 & 1.30539 & \multirow[t]{2}{*}{1.166} & \multirow[t]{2}{*}{.246} \\
\hline & Female & 110 & 18.7091 & 1.30170 & & \\
\hline \multirow[t]{2}{*}{ Performing Tasks Completely and Effectively } & Male & 45 & 18.8222 & 1.23009 & \multirow[t]{2}{*}{.887} & \multirow[t]{2}{*}{.376} \\
\hline & Female & 110 & 18.6182 & 1.32708 & & \\
\hline \multirow[t]{2}{*}{ Clarity of Thought and Expression } & Male & 45 & 18.8000 & 1.28982 & \multirow[t]{2}{*}{.146} & \multirow[t]{2}{*}{.884} \\
\hline & Female & 110 & 18.7636 & 1.45846 & & \\
\hline
\end{tabular}

The Table 7 shows the results of an independent t-Test for gender-based leadership skills, the $\mathrm{P}$ value for $\mathrm{t}$-Test is 0.019 , which is lower than the significant $\alpha=0.05(\mathrm{p}<0.05)$ level, so there is a significant difference between gender-based leadership skills. For effective gender-based listening, the results of the analysis show that the value of $\mathrm{P}$ for t-Test is 0.246 , which is greater than the significant level of $\alpha=0.05$ 
$(\mathrm{p}<0.05)$, there is no significant difference between the role of effective communication and effective gender-based listening. Next, to perform tasks completely and effectively on the basis of gender, the results of the analysis show that the value of $\mathrm{P}$ for $\mathrm{t}$-Test is 0.376 , which is greater than the significant level of $\alpha=0.05 \quad(p<0.05)$, means that there is no significant difference between the role of effective communication performing tasks completely and effectively on the basis of gender. Finally, with regard to gender-based clarity of thought and expression, the results of the analysis show that the value of $\mathrm{P}$ for $\mathrm{t}$ Test is 0.884 , which is greater than the significant level of $\alpha=0.05(\mathrm{p}<0.05)$. It means that there is no significant difference between the role of effective communication, which is gender-based clarity of thought and expression.

\section{Differences in the Role of Effective Communication in Enhancing Leadership Skills Based on Age of Students}

Differences in the role of effective communication in enhancing student age-based leadership skills are supported by the One Way ANOVA analysis. The results of this analysis are shown in the following table:

Table 8: Results of One Way ANOVA Analysis

\begin{tabular}{|c|c|c|c|c|c|c|}
\hline Variables & & $\begin{array}{c}\text { Sum of } \\
\text { Squares }\end{array}$ & df & Mean Square & $\mathrm{F}$ & Sig. \\
\hline \multirow[t]{3}{*}{ Leadership Skills } & $\begin{array}{l}\text { Between } \\
\text { Groups }\end{array}$ & .684 & 2 & .342 & \multirow[t]{3}{*}{.223} & \multirow[t]{3}{*}{.800} \\
\hline & Within Groups & 232.735 & 152 & 1.531 & & \\
\hline & Total & 233.419 & 154 & & & \\
\hline \multirow[t]{3}{*}{ Effective Listening } & $\begin{array}{l}\text { Between } \\
\text { Groups }\end{array}$ & 6.475 & 2 & 3.237 & \multirow[t]{3}{*}{1.926} & \multirow[t]{3}{*}{.149} \\
\hline & Within Groups & 255.499 & 152 & 1.681 & & \\
\hline & Total & 261.974 & 154 & & & \\
\hline \multirow[t]{3}{*}{ Tasks Completely } & $\begin{array}{l}\text { Between } \\
\text { Groups }\end{array}$ & 3.119 & 2 & 1.560 & \multirow[t]{3}{*}{.923} & \multirow[t]{3}{*}{.399} \\
\hline & Within Groups & 256.752 & 152 & 1.689 & & \\
\hline & Total & 259.871 & 154 & & & \\
\hline \multirow[t]{3}{*}{ Clarity of Thought and Expression } & $\begin{array}{l}\text { Between } \\
\text { Groups }\end{array}$ & 13.328 & 2 & 6.664 & \multirow[t]{3}{*}{3.472} & \multirow[t]{3}{*}{.034} \\
\hline & Within Groups & 291.768 & 152 & 1.920 & & \\
\hline & Total & 305.097 & 154 & & & \\
\hline
\end{tabular}

The results of the analysis show that age-based leadership skills have a $\mathrm{p}$-value $=0.800$ higher than a significant $\alpha=0.05$. Efficient age-based listening has a p-value of 0.149 greater than a significant level $\alpha=0.05$. The $p$-value $=0.399$ is greater than the significant $\alpha=0.05$ for performing tasks completely and effectively based on age. Age-based clarity of thought and expression has only a lower p-value $=0.034$ lower than the significant level $\alpha=0.05$. The results show that there is only clarity of thought and expression that affects the role of effective communication in enhancing student age-based leadership skills. To date, the results of the analysis show that there are differences that are significant among each group.

\section{To Examine whether Effective Listening, Performing Tasks Completely and Effectively, and Clarity of Thought and Expression toward Leadership Skills}

The statistical analysis that has been used are regression. This is a test of the model's overall fitness. The hypothesis that was tested concerned with the selected independent variables that influence the dependent variable. 
Table 10: Multiple Regression Analysis

\begin{tabular}{|c|c|c|c|c|c|c|c|}
\hline & \multirow[t]{2}{*}{ B } & \multirow[t]{2}{*}{ Beta } & \multirow[t]{2}{*}{$\mathrm{P}$} & \multicolumn{2}{|c|}{$\begin{array}{c}\text { Collinearity } \\
\text { Statistic }\end{array}$} & \multirow[t]{2}{*}{$\begin{array}{c}\mathrm{R} \\
\text { square }\end{array}$} & \multirow[t]{2}{*}{$\begin{array}{c}\text { Adjust d R } \\
\text { square }\end{array}$} \\
\hline & & & & TOL & VIF & & \\
\hline Constant & 11.919 & & & & & .116 & .098 \\
\hline Effective Listening & .124 & .131 & .127 & .805 & 1.243 & & \\
\hline Performing Tasks Completely and Effectively & .248 & .262 & .005 & .688 & 1.453 & & \\
\hline Clarity of Thought and Expression & .000 & .000 & .999 & .801 & 1.249 & & \\
\hline
\end{tabular}

The regression equation for full model was as follows:

Leadership skills $=11.919+0.124$ (Effective Listening $)+0.248$ (Performing Tasks Completely and Effectively) +0.000 (Clarity of Thought and Expression).

Based on the Table 10, there was no multicollinearity as the variation inflation factor (VIF) was less than ten for all variables. As a result, it has been found that the $p$-value $=0.005$ is less than $\alpha=0.05$ only to perform tasks completely and effectively, so that it has a significant effect on leadership skills. While the result of effective listening and clarity of thought and expression shows that $\mathrm{p}$-value $=0.127$ and $\mathrm{p}$-value $=$ 0.999 are more than $\alpha=0.05$, the two independent variables did not have a significant effect on leadership skills.

The coefficient of determination, R-square in Table 10, shows that only $11.6 \%$ of the variation in dependent variables, leadership skills can be explained by independent variables, students at this university have high knowledge of performing tasks in a complete and effective manner. The adjusted R-Squared is 9.8\%, which is the dependent variable, and leadership skills are not sufficiently explained by the independent variables.

The study was tested on fourteen paths representing the hypotheses $\left(\mathrm{H}_{8}, \mathrm{H}_{9}, \mathrm{H}_{10}, \mathrm{H}_{13}\right.$ and $\left.\mathrm{H}_{14}\right)$ which were found to be statistically significant. Table 11 presents summary of the result of the hypotheses testing.

Table 11: Summary of Hypothesis Test Results

\begin{tabular}{|c|c|c|}
\hline & Hypothesis Statement & Results \\
\hline $\mathrm{H}_{1}$ & There is significant difference in effective listening to their gender. & $\begin{array}{l}\text { Not } \\
\text { significant }\end{array}$ \\
\hline $\mathrm{H}_{2}$ & There is significant difference in effective listening to their age. & $\begin{array}{l}\text { Not } \\
\text { significant }\end{array}$ \\
\hline $\mathrm{H}_{3}$ & There is significant difference in effective listening to their semester. & $\begin{array}{l}\text { Not } \\
\text { significant }\end{array}$ \\
\hline $\mathrm{H}_{4}$ & There is significant difference in performing tasks completely and effectively to their gender. & $\begin{array}{l}\text { Not } \\
\text { significant }\end{array}$ \\
\hline $\mathrm{H}_{5}$ & There is significant difference in performing tasks completely and effectively to their age. & $\begin{array}{l}\text { Not } \\
\text { significant }\end{array}$ \\
\hline $\mathrm{H}_{6}$ & There is significant difference in performing tasks completely and effectively to their semester. & $\begin{array}{l}\text { Not } \\
\text { significant }\end{array}$ \\
\hline $\mathrm{H}_{7}$ & There is significant difference in clarity of thought and expression to their gender. & $\begin{array}{l}\text { Not } \\
\text { significant }\end{array}$ \\
\hline $\mathrm{H}_{8}$ & There is significant difference in clarity of thought and expression to their age. & Significant \\
\hline $\mathrm{H}_{9}$ & There is significant difference in clarity of thought and expression to their semester. & Significant \\
\hline $\mathrm{H}_{10}$ & There is significant difference in leadership skills to their gender. & Significant \\
\hline $\mathrm{H}_{11}$ & There is significant difference in leadership skills to their age. & $\begin{array}{l}\text { Not } \\
\text { significant }\end{array}$ \\
\hline $\mathrm{H}_{12}$ & There is significant difference in leadership skills to their semester. & $\begin{array}{l}\text { Not } \\
\text { significant }\end{array}$ \\
\hline
\end{tabular}




\begin{tabular}{llll}
\hline $\mathrm{H}_{13}$ & $\begin{array}{l}\text { There is significant relationship between effective listening, performing tasks completely and } \\
\text { effectively, and clarity of thought and expression and leadership skills. }\end{array}$ & Significant \\
\hline $\mathrm{H}_{14}$ & $\begin{array}{l}\text { There is significant influence of the effective listening, performing tasks completely and effectively, } \\
\text { and clarity of thought and expression toward leadership skills. }\end{array}$ & Significant \\
\hline
\end{tabular}

\section{CONCLUSION AND RECOMMENDATIONS}

In summary, it can conclude that students at UiTM Perlis from FSKM appear to be aware of the role of effective communication in enhancing leadership skills among university students. There is a positive relationship between the role of effective communication and leadership skills, but a great deal of determination is still needed to establish leadership criteria among undergraduates, as there have been a few students who are not aware of the importance of leadership skills in their future careers. In addition, the role of effective communication in enhancing leadership skills among university students must be properly studied so that students can develop their ability to soon become major leaders.

Further research needs to be carried out in the future based on the study that I have carried out. The first recommendation for future research is to increase the number of respondents to answers the questionnaire because it helps to influence the collection of data. If more respondents are involved in this study, the data collected will be more accurate and the information collected will be clearer. Next, a further recommendation for future research that can be suggested is to study at another university, either locally or internationally. The researcher can have different associations between students from different study locations, as they will provide different leadership backgrounds. Moreover, it is important for students to develop effective communication skills to enhance leadership skills in the future, especially in finding a job, because they may feel that they are a leader in this study.

\section{REFERENCES}

Abdan, N. B. (2015). Role of effective communications enhancing leadership skill on FPTV student. International Journal of Science and Research, 4(5), 1791-1794.

Akilandeswari, V., Dinesh Kumar, A. \& Philomin Freeda, A. \& Niranchan Kumar, S. (2015). Elements of Effective Communication. New Media and Mass Communication, 37(2015), 44-47.

Ary, D., Jacobs, L. C. \& Razavieh, A. (2002). Introduction to Research in Education. New York : Belmont, CA Wadsworth.

Ayub, S. H., Manaf, N. A. \& Hamzah, M. R. (2014). Leadership: Communicating Strategically in the 21st Century. Procedia - Social and Behavioral Sciences, 155, 502-506. doi: 10.1016/j.sbspro.2014.10.330

Burg (2020). How to ensure clarity in your communication. Retrieved from https://www.bizjournals.com/bizjournals/how-to/growth-strategies/2016/02/how-to-ensure-clarity-inyour-communication.html

Caspersz, D. \& Stasinska, A. (2015). Can we teach effective listening? An exploratory study. Journal of University Teaching \& Learning Practice, 12(4).

Henderson, A. (2015). Leadership and communication: What are the imperatives?. Journal of Nursing Management, 23(6), 693-694. doi: 10.1111/jonm.12336 
Kelvin, L. (2016). The Role of Effective communication in strategic management of organizations. International Journal of Humanities and Social Science, 6(12), 93-99.

Keyton, J. (2011). Communication and Organizational Culture: A Key to Understanding Work Experience. Thousand Oaks, CA: Sage.

Luthra, A. \& Dahiya, R. (2015). Effective leadership is all about communicating effectively: connecting leadership and communication. International Journal of Management \& Business Studies, 5(3), 43-48.

Sekaran, U. \& Bougie, R. (2010). Research Methods for Business: A Skill-Building approach. Haddington: John Wiley \& Sons.

Wikaningrum, T., Achmad Saef, U. \& Yuniawan, A. (2018). The relationships among leadership styles, communication skills, and employee satisfaction: A study on equal employment opportunity in leadership. Journal of Business and Retail Management Research, 13(1), 138-147. 